therefore provide a mechanism whereby cigarette smoking predisposes to cardiovascular disease.

1 Freedman DS, Srinivasan SR, Shear CL, et al. Cigarette smoking initiation and longitudinal changes in serum lipids and lipoproteins in early adulthood: the Bogalusa heart study. $\mathbf{A m} \mathcal{F}$ Epidemiol 1986;124:207-19.

2 Elkeles ES, Khan SR, Chowdhury V, Swallow MB. Effects of smoking on oral fat tolerance and high density lipoprotein cholesterol. Clin Sci 1983;65:669-72.

3 Lewis B, Boberg.J, Carlson LA. Determination of the intravenous fat tolerance test with Intralipid by nephelometry. Atherosclerosis 1972;15:83-6.

4 Patsch JR, Prasad S, Gotto AM, Bengtsson-Olivecrona G. Postprandial lipemia. A key for the conversion of high density lipoprotein2 into high density lipoprotein 3 by hepatic lipase. $\mathcal{J}$ Clin Invest 1984;74:2017-23.

5 Miller NE, Hammett F, Saltissi S, et al. Relation of angiographically defined coronary artery disease to plasma lipoprotein subfractions and apolipoproteins. Br Med f 1981;282:1741-3.

(Accepted 24 April 1987)

Departments of Chemical Pathology and Medicine, St Mary's Hospital, London W2 1NY

W RICHMOND, PHD, principal biochemist

$P$ W SEVIOUR, MB, MRCP, research fellow

T K TEAL, BSC, MRCPATH, senior biochemist

R S ELKELES, MD, FRCP, consultant physician

\section{Analgesic effect of somatostatin analogue (octreotide) in headache associated with pituitary tumours}

Headache associated with pituitary tumours is occasionally severe and may be refractory to opiate analgesics and even attempted pituitary ablation. During clinical trials of a long acting somatostatin analogue (octreotide; SMS201-995) in acromegaly some patients spontaneously reported dramatic improvement in chronic severe headache. ${ }^{1}$ Analgesia was not related to either suppression of growth hormone or tumour shrinkage. ${ }^{1}$ These findings prompted a formal placebo controlled double blind study of the effects of octreotide on headache associated with pituitary tumour.

\section{Patients, methods, and results}

We studied six patients (table) with severe headache for one to 16 years for which no other cause had been found. Five patients (cases 1-5): had acromegaly previously treated by interstitial or external beam pituitary irradiation, or both, in each case and by hypophysectomy in one. Treatment had substantially reduced growth hormone concentrations in all cases (with obvious tumour shrinkage in cases 2-4), but headache had persisted. Two patients (cases 2 and 3) were particularly incapacitated and were often confined to bed and unable to work; opiate analgesics were ineffective. One patient (case 6) had a macroprolactinoma with normal growth hormone secretion. During 15 months of bromocriptine $(7 \cdot 5-15.0 \mathrm{mg} / \mathrm{day}$, discontinued four weeks before the study) the size of the tumour was unchanged and headache only slightly improved, apart from several acute exacerbations attributed to episodes of minor tumour infarction.
The study was performed in hospital at least two days after stopping analgesics. The patients recorded severity of headache on an unmarked $10 \mathrm{~cm}$ visual analogue scale ranging from "no headache" to "worst headache ever" at 0900 , 1500 , and 2100 and one and three hours after these times. After a run in day (no injections) octreotide $(100 \mu \mathrm{g}$ in $1 \mathrm{ml}$ ) and placebo ( $1 \mathrm{ml}$ octreotide diluent; sodium acetate-acetic acid buffer, $\mathrm{pH} 4.0$ ) were injected alternately at the above times for four days. Injections were given double blind, subcutaneously in the abdomen, by medical staff; both injections caused transient burning discomfort.

Headache scores (distance from "no headache" end of scale) one and three hours after each injection were expressed as the percentage of the value immediately before injection. Differences between octreotide and placebo in percentage score one and three hours after injection were examined by the paired $t$ test.

In three patients with acromegaly (cases 1-3) headache improved dramatically within two to 10 minutes after every injection of octreotide and virtually disappeared in cases 2 and 3 . Headache scores at one and three hours were significantly less than after placebo, which had no analgesic effect (table). Relief lasted up to six hours. As reported previously, the patient with macroprolactinoma (case 6) also showed a significant analgesic response to the active drug but not to placebo (table) ${ }^{2}$ The remaining two patients with acromegaly (cases 4 and 5), however, showed no improvement with octreotide.

The patient in case 3 subsequently continued octreotide $(100 \mu \mathrm{g}$ self injected every six to eight hours) for over six months. Analgesia remained effective and it was possible to withdraw opiate analgesics. There were no clinical or biochemical complications of treatment.

\section{Comment}

This study shows that octreotide can relieve chronic, life disrupting headache associated with acromegaly, (both active and inactive) and prolactinoma. Though headache is traditionally attributed to the space occupying effects of the tumour, other factors must contribute, as severity of the headache correlates only poorly with tumour size. Analgesia with octreotide occurs too rapidly to be explicable by tumour shrinkage, which in any case occurs in only a few patients with acromegaly after long term treatment with the drug. ${ }^{1}$ Native somatostatin injected intrathecally causes segmental anaesthesia, possibly by inhibiting pain induced substance $P$ release in the dorsal horn of the cord ${ }^{3}$; octreotide might similarly prevent substance $P$ release in the trigeminal nucleus, thus blocking transmission of painful impulses from the pituitary fossa. ${ }^{34}$ An interesting hypothetical possibility is that octreotide may suppress secretion by the pituitary tumour of "algesic" peptides which may cause pain, perhaps by interfering with the actions of endogenous analgesic peptides such as the endorphins or kyotorphins. ${ }^{\text {s }}$

The rapid and effective analgesic action of octreotide suggests that it should be considered in patients with intractable headache associated with pituitary tumours.

We are grateful to Dr Carolyn Greenwood-Wigart and Sandoz UK Limited for supplies of octreotide and its diluent, and to Mrs Jacqui Chatterton for typing the manuscript. GW is supported by the British Diabetic Association and JAB is an MRC training fellow.

1 Sandler LM, Burrin JM, Williams G, Joplin GF, Carr DH, Bloom SR. Effective long-term treatment of acromegaly with a long-acting somatostatin analogue (SMS 201-995). Clin Endocrinol 1987;26:85-95.

2 Williams G, Ball J, Bloom SR, Joplin GF. Improvement in headache associated with prolactinoma during treatment with a somatostatin analogue: an "n of l" study. $N$ Engl I Med 1986;315: $1166-7$.

\begin{tabular}{|c|c|c|c|c|c|c|c|c|c|c|c|}
\hline \multirow[b]{3}{*}{$\begin{array}{l}\text { Case } \\
\text { No }\end{array}$} & \multirow{3}{*}{$\begin{array}{l}\text { Sex } \\
\text { and } \\
\text { age } \\
\text { (years) }\end{array}$} & \multirow[b]{3}{*}{ Diagnosis } & \multirow[b]{3}{*}{ Treatment and year } & \multirow{3}{*}{$\begin{array}{l}\text { Tumour anatomy } \\
\text { (computed tomography) }\end{array}$} & \multirow{3}{*}{$\begin{array}{c}\text { Serum } \\
\text { growth } \\
\text { hormonet } \\
\text { (normal } \\
<2 \mathrm{mU} / \mathrm{l})\end{array}$} & \multirow{3}{*}{$\begin{array}{c}\text { Mean } 24 \text { hour } \\
\text { serum prolactin } \\
\text { (normal } \\
75-375 \mathrm{mU} / 1 \\
\text { (men); } \\
125-625 \mathrm{mU} / 1 \\
\text { (women)) }\end{array}$} & \multirow{3}{*}{$\begin{array}{c}\begin{array}{c}\text { Year } \\
\text { of } \\
\text { headache } \\
\text { onset }\end{array}\end{array}$} & \multicolumn{4}{|c|}{$\begin{array}{l}\text { Mean (SEM) headache responses } \\
\text { (\% of preinjection headache score) }(n=6)\end{array}$} \\
\hline & & & & & & & & \multicolumn{2}{|c|}{ Octreotide } & \multicolumn{2}{|c|}{ Placebo } \\
\hline & & & & & & & & 1 Hour & 3 Hours & 1 Hour & 3 Hours \\
\hline 1 & $M, 46$ & Acromegaly & ${ }^{90} \mathrm{Y}$ Implantation ( $\left.500 \mathrm{~Gy}\right)$ & $5 \mathrm{~mm}$ Suprasellar extension & 11 & 407 & 1981 & $2(0.5)^{\star}$ & $3(0.5)^{\star}$ & $160(45)$ & 440 (149) \\
\hline 2 & $M, 27$ & Acromegaly & $\begin{array}{l}\left.{ }^{90} \text { Y Implantation ( } 1.5 \mathrm{kGy}\right) \\
\text { 1982; external beam }\end{array}$ & Partially empty sella & 26 & 180 & 1980 & $1(0 \cdot 1)^{\star}$ & $i(0 \cdot 1)^{\star}$ & $124(14)$ & $144(25)$ \\
\hline 3 & M, 39 & Acromegaly & $\begin{array}{l}\text { 90Y Implantation ( } 500 \mathrm{~Gy}), \\
\text { 1970; hypophysectomy,' } \\
\text { 1970; external beam } \\
\text { radiotherapy ( } 40 \mathrm{~Gy}), 1984\end{array}$ & $18 \mathrm{~mm}$ Lateral extension & 7 & $<100$ & 1970 & $55(6)^{\star}$ & $69(7)^{\star}$ & $146(35)$ & $192(21)$ \\
\hline 4 & $M, 45$ & Acromegaly & $\begin{array}{l}\text { External beam radiotherapy } \\
(40 \mathrm{~Gy}), 1984\end{array}$ & Partially empty sella & 9 & 271 & 1981 & $107(10)$ & $111(24)$ & $131(76)$ & $145(76)$ \\
\hline 5 & $F, 68$ & Acromegaly & $\begin{array}{l}\text { External beam radiotherapy } \\
(40 \mathrm{~Gy}), 1977\end{array}$ & Partially empty sella & 1 & 1933 & 1977 & $105(3)$ & $147(38)$ & $191(55)$ & $390(157)$ \\
\hline 6 & F, 37 & Prolactinoma & Bromocriptine, 1985 & $6 \mathrm{~mm}$ Suprasellar extension & $<1$ & 5000 & 1985 & $52(9)^{\star}$ & $51(16)^{\star}$ & $294(160)$ & $730(468)$ \\
\hline
\end{tabular}

${ }^{90} \mathrm{Y}=$ Yttrium-90.

${ }^{\star} \mathrm{p}<0.01$ Compared with placebo.

† Mean of values at 60,90 , and 120 minutes after $50 \mathrm{~g}$ glucose by mouth. 
3 Randic M, Miletic V. Depressant actions of methionine-enkephalin and somatostatin in cat dorsa horn neurones activated by noxious stimuli. Brain Res 1978;152:196-202.

4 Hökfelt T, Kellerth JO, Nilsson G, Pernow B. Experimental immunohistochemical studies on the localization and distribution of substance $\mathrm{P}$ in cat primary sensory neurones. Brain Res 1975; 100:235-52.

5 Takagi H, Shiomi H, Fukui K, Hayashi K, Kiso Y, Kitagawa K. Isolation of a novel analgesic pentapeptide, neokyotorphin, from bovine brain. Life Sci 1982;31:1733-6.

(Accepted 11 June 1987)

Department of Medicine, Royal Postgraduate Medical School, London W12 0HS

GARETH WILLIAMS, MD, MRCP, R D Lawrence research fellow, honorary senior registrar

JOANNA A BALL, MB, MRCP, research registrar

RODERICK A LAWSON, MB, senior house officer

GRAHAM F JOPLIN, PHD, FRCP, professor of clinical endocrinology

STEPHEN R BLOOM, MD, FRCP, professor of endocrinology

St Bernard's Hospital, Gibraltar

MICHAEL R MASKILL, MB, MRCP, consultant physician

Correspondence to: Professor Bloom.

\section{Reactive arthritis associated with cryptosporidium enteritis}

Enteric infection with cryptosporidium is now increasingly recognised as a cause of diarrhoea in man. The incidence appears to vary geographically and throughout the year, cases being reported most commonly in the late summer and early autumn. ${ }^{1}$ In immunocompetent patients the illness is self limiting, lasting from seven to 10 days, but immunocompromised patients may be severely affected with life threatening and protracted diarrhoea. ${ }^{2}$ There is no effective antimicrobial treatment. The clinical manifestation of watery, non-bloody diarrhoea is not specific to this organism. Vomiting is common initially together with abdominal pain, which is sometimes severe and may precede the diarrhoea. Although a malabsorption syndrome may occasionally follow the acute episode, there have been no other long term sequelae in immunocompetent patients. We describe a case of cryptosporidium enteritis associated with reactive arthritis.

\section{Case report}

A 27 year old man was admitted from the casualty department, where he had presented with an acutely swollen, painful right knee of 24 hours' duration and arthralgias affecting his neck, lower back, and left knee for 12 hours. He had no previous history of joint symptoms. He had been well until seven days before admission, when he had developed colicky, abdominal pain associated with anorexia, nausea, and vomiting followed by two days of severe, watery diarrhoea for which he had been prescribed loperamide. A neighbour (aged 5 years) had also had diarrhoea one week. earlier. There was no history of conjunctivitis or urethritis.

On examination the right knee was hot, swollen, tender, held in slight flexion, and extremely painful when moved. After admission he had no further bowel symptoms but continued to have severe arthralgias, which progressed to include his wrists and left heel. There was a persistent effusion of the right knee. Treatment was symptomatic with naproxen in conventional dosage and bed rest, but it was only partly effective. He was discharged after one week, but on review a week later he had persistent arthralgias and increasing pain in his right knee. The joint was aspirated and, after a culture of the synovial fluid gave negative results, it was injected with steroid and it subsequently settled. He improved slowly, but four months later he still had mild arthralgia, particularly in his knees.

The results of the following investigations were normal or negative: full blood count; electrolytes; immunoglobulins; rheumatoid factor; autoantibodies; antistreptolysin $\mathrm{O}$ titre; and antibodies to Campylobacter jejuni, Yersinia enterocolitica Salmonella typhi, and $S$ paratyphi. The erythrocyte sedimentation rate was $66 \mathrm{~mm}$ in the first hour. Examination of a rectal swab showed no evidence of shigella, campylobacter, or salmonella, but oocysts of cryptosporidium were identified Human leucocyte antigen B27 (HLA-B27) typing was negative.

\section{Comment}

In this patient the temporal relation between the diarrhoea and the arthropathy, together with the sterile effusion, suggested reactive arthritis. Although this is well recognised after infection with a number of other intestinal pathogens, including salmonella, shigella, $Y$ enterocolitica, and $C$ jejuni, ${ }^{34}$ there are no reports of reactive arthritis secondary to infection with cryptosporidium. Only a few patients with bowel infection develop reactive arthritis. Genetic factors, including the presence of HLA-B27, are thought to play a part in the pathogenesis and clinical expression of the spond- arthritides. HLA-B27 is present in up to $63 \%$ of patients with Reiter's syndrome and it correlates with uveitis, severe constitutional upset, and a chronic or relapsing course. ${ }^{5}$ The underlying mechanisms are not completely understood, and the occurrence of reactive arthritis in a patient negative for HLA-B27 suggests that an additional gene or genes may be implicated. Since techniques have become available for the rapid detection of cryptosporidium oocysts in the stools an increasing number of laboratories are including these tests in the routine investigation of patients with diarrhoea. Following this report cryptosporidium infection should be considered as a possible causal agent in patients with diarrhoea that gives negative results on culture and reactive arthritis.

1 Bissenden JG. Cryptosporidium and diarrhoea. $\mathrm{Br} \mathrm{Med} \mathcal{F}$ 1986;293:287-8.

2 Malebranche R, Arnovx E, Guerin JM, et al. Acquired immunodeficiency syndrome with severe gastrointestinal manifestation. Lancet 1983;ii:487-9.

3 Larsen JH. Yersinia enterocolitica infections and arthritis. In: Dumonde DC, ed. Infection and immunology in the rheumatic diseases. Oxford: Blackwell, 1976;17:133-40.

4 Kosunen TU, Pönkä A, Kauraneno O, el al. Arthritis associated with campylobacter enteritis.

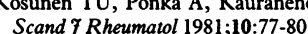

5 McClusky OE, Lordon RE, Arnett FC. HL-A 27 in Reiter's syndrome and psoriatic arthritis: a genetic factor in disease susceptibility and expression. $\mathcal{F}$ R heumatol 1984;11:571.

(Accepted 24 April 1987)

Department of Rheumatology, Nether Edge Hospital, Sheffield S11 9EL

E M HAY, MRCP, registrar in rheumatology

J WINFIELD, MRCP, consultant in rheumatology and rehabilitation

Department of Medicine and Communicable Diseases, Lodge Moor Hospital, Sheffield

M W McKENDRICK, MRCP, consultant physician

Correspondence to: Dr Winfield.

\section{A simple and effective treatment for AIDS related Kaposi's sarcoma}

About a third of British patients with the acquired immune deficiency syndrome (AIDS) have Kaposi's sarcoma, ${ }^{1}$ which is usually diagnosed before there is evidence of immune deficiency. Characteristically the lesions are purplish blue infiltrated patches that may occur on all parts of the skin and mucous membranes, especially the trunk, face, penis, and palate. Though the disease may pursue an aggressive course, it is usually only a disfiguring and distressing precursor of and accompaniment to the opportunistic infections of which patients with AIDS usually die.

Epidemic Kaposi's sarcoma may be treated with chemotherapy, immunotherapy, or radiotherapy. ${ }^{2 \cdot 4}$ Local radiotherapy has minimal side effects and is an effective way of producing regression of individual lesions. Furthermore, it does not cause immunosuppression and so does not affect the prognosis of either the AIDS or the generalised Kaposi's sarcoma. Reduction in size and control of enlarging lesions, especially on the face or feet, may appreciably improve the quality of life of patients with AIDS. We describe the first series reported from Britain of patients with epidemic Kaposi's sarcoma treated with local radiotherapy by means of a single fraction irradiation technique.

Patients, methods, and results

Patients with Kaposi's sarcoma were referred for possible radiotherapy by their general practitioners, the department of medicine and genitourinary medicine at this hospital, and the St John's Hospital for Diseases of the Skin, London. The indications for irradiation were an increase in size of the tumours, lesions that were bleeding, particularly on the feet (which may not only restrict mobility but are also a potential source of infection), and pedunculated and ulcerated palatal lesions. These last cause soreness of the mouth, instability of teeth, and eventually dyspnoea and dysphagia. Small cosmetically distressing lesions on the face were also treated.

The table gives details of the patients treated, dose of radiation and number of treatment sessions, and outcome. In all patients radiotherapy resulted in at least partial regression of all the lesions treated.

\section{Comment}

The lesions of Kaposi's sarcoma in patients with AIDS are seldom life threatening but frequently cause considerable discomfort and emotional distress. Local palliative irradiation of troublesome patches is an effective way of controlling these lesions without causing immunosuppression.

Our experience suggests the following approach to treatment. Lesions 